\title{
Production Aspects of Broiler Breeders Submitted to Different Drinker Types
}

\section{-Author(s)}

Colvero LP

Carrijo AS'

Garófallo RG

Bernardi R"

Steffen RPB'II

Stefanello CIII

Department of Animal Science, School of Veterinary Medicine and Animal Science, Universidade Federal de Mato Grosso do Sul, Campo Grande، MS, Brazil

" School of Agricultural Sciences, Universidade Federal da Grande Dourados, Dourados, MS, Brazil

III Center of Rural Sciences, Universidade Federal de Santa Maria (UFSM), Santa Maria, RS, Brazil

\section{nail Adress}

Corresponding author e-mail address Lucas Pedroso Colvero

Caixa Postal 336, CEP:89801-974

Chapecó-SC, Brazil

E-mail: ko.vs@hotmail.com

\section{-Keywords}

Intake, gravity, nipple drinkers, bell drinker, egg production.

\section{ABSTRACT}

The objective of this study was of evaluate the influence of different drinker types on the egg production, water intake, mortality, poultry litter relative humidity, egg weight, eggshell percentage, and egg specific gravity of broiler breeders. The experiment was carried out in a commercial farm with 37- to 44-wk-old broiler breeders. A randomized block experimental design, consisting of two treatments (bell or nipple drinkers) with four replicates of 4.000 females each, was applied. Data were submitted to analysis of variance, and means were compared by the test of Student-Newman-Keuls at 5\% significance level. Birds submitted to nipple drinkers presented lower water intake $(p<0.05)$. There was no influence ( $p>0.05$ ) of drinker type on egg production or mortality. Poultry litter relative humidity was lower $(p<0.05)$ under the nipple-drinker system. Birds drinking from bell drinkers produced heavier eggs $(p<0.05)$ between weeks 39 and 40 . Hens drinking from bell drinkers laid eggs with higher specific gravity and eggshell percentage. It was concluded that nipple drinkers can be used for broiler breeders during lay.

\section{INTRODUCTION}

Poultry production has greatly developed in Brazil during the last decades, and chicken meat is one of the main exports products in the country. This progress has fostered research aiming at improving live performance, particularly studies on the formulation of low-cost diets, since feeding represents the largest cost in poultry production (Carneiro et al., 2009)

Considering all nutrients, water is often overlooked and subject of few studies. However, it plays essential metabolic roles, such as body temperature control, feed digestion and absorption, and excretion of waste products in the urine, and therefore should be supplied in sufficient amounts and adequate quality to animals (Quichimbo et al., 2013). Watkins (2002) states that poultry performance is directly related with the quantitative and qualitative characteristics of water supply.

Jafari (2006) and Karimi et al. (2011) isolated Escherichia coli and Salmonella from water samples collected from bell drinkers, demonstrating that drinking water can disseminate pathogens in poultry flocks. Gama et al. (2009) showed the positive effects of filtered drinking water on the performance of commercial layers.

Bell drinkers and nipple drinkers are the two main drinking water systems applied in poultry production, and studies comparing their influence on broiler and commercial layer performance have been carried out. May et al. (1997) and Bruno et al. (2011), comparing the management of nipple and bell drinkers in commercial layer and broiler production, respectively, describe the qualities and peculiarities of each system and provide information on their correct management. 
Nevertheless, Soares et al. (2012) noted that the current results are incipient and contradictory. In addition, information on the influence of drinker type on broiler breeder in the production stage is lacking, and this knowledge is critical because, according to Manning et al. (2007), water quality and water intake are indicators of animal welfare.

In this context, this study aimed at evaluating the influence of bell and nipple drinkers on the egg production, water intake, mortality, poultry litter relative humidity, and egg quality of broiler breeders during lay.

\section{MATERIALS AND METHODS}

The study was carried out in a broiler breeder farm located in Jataí, state of Mato Grosso do Sul, Brazil, between March 29 and May 24 of 2009. Birds were housed in four conventional commercial broiler breeder houses equipped with trough feeders, positive ventilation system, and wood-shavings litter. The experimental flock consisted of 32,000 Ross 308 females broiler breeders selected according to body weight. Birds were submitted to an adaptation period (beginning and peak of lay) between 23 and 37 weeks of age. Birds were fed according to a daily restricted feeding regime, with feed allowances and nutritional levels calculated according to the recommendations of the Ross 308 manual (Aviagen, 2008). Drinking water contained 3-5 ppm chlorine, and was supplied either in nipple drinkers with drop cups, at a density of 10 birds per nipple and flow rate of $100-120 \mathrm{~mL} / \mathrm{min}$, or in bell drinkers, at a density of 80 birds per drinker. Bell drinkers were daily cleaned during the afternoon with a disinfectant solution.

Birds were 37- to 44-weeks-old during the experiment, when data relative to the evaluated parameters (egg production, mortality, water intake, poultry litter relative humidity, egg weight, eggshell percentage, and egg specific gravity) were determined. Eggs were manually collected seven times per day and identified per treatment and replicate. Environmental temperature and water intake were daily measured at 07:00 h using thermo-hygrometers and flow meters, respectively.

Litter was weekly collected in three previously determined spots per replicate to determine litter relative humidity. Litter samples were homogenized, dried in an oven at $105^{\circ} \mathrm{C}$ for 3 hours, and then placed in a desiccator until temperature was stabilized. Litter relative humidity was calculated as the difference between sample initial and final weight relative to sample initial weight.
Water intake was determined as the ratio between water volume measured by the flow meter and average bird weight, obtained by weekly weighing $5 \%$ of the birds in each replicate.

Drinking water was microbiologically monitored by weekly collecting $500 \mathrm{~mL}$ of water per replicate, which were analyzed for total coliforms, fecal coliforms, and Escherichia coli.

Egg quality was determined in 330 settable eggs collected daily per replicate. Egg specific gravity was determined by the method of floating in buckets with increasing concentrations of saline solution $(\mathrm{NaCl})$ of 1.065 to 1.090 at 0.005 intervals daily calibrated using a densitometer. Eggs were individually weighed in a $0.5 \mathrm{~g}$ precision scale, and were then broken to weigh their shells.

A randomized block experimental design with two treatments (bell drinker or nipple drinker), each with four replicates (pens) of 4,000 birds, was applied. Data were submitted to analysis of variance, and means were compared by the test of Student-Newman-Keuls at $5 \%$ significance levels, using the Statistical Analisys System (SAS, 2001) statistical package.

\section{RESULTS AND DISCUSSION}

There was no influence of drinker type on egg production during the evaluated period (Table 1). Togashi et al. (2008), working with commercial layers, observed significantly higher egg production and better feed conversion ratio when layers drank from nipple drinkers compared with those using cup drinkers. Macari (1996), on the other hand, reported higher egg production with trough drinkers than with nipple drinkers. In the study of Klosowisk et al. (2009) with commercial layers, there was no influence of trough or nipple drinkers on egg production.

Table 1 - Weekly egg production (\%) of broiler breeders as a function of drinker type.

\begin{tabular}{ccccc}
\hline Week & Bell drinker & $\begin{array}{l}\text { Nipple } \\
\text { drinker }\end{array}$ & CV (\%) & P value \\
\hline 37 & 80.15 & 79.49 & 2.93 & 0.2987 \\
38 & 80.11 & 78.59 & 4.60 & 0.1254 \\
39 & 78.85 & 79.85 & 2.57 & 0.0694 \\
40 & 77.98 & 77.21 & 2.89 & 0.2011 \\
41 & 76.62 & 76.08 & 2.59 & 0.3112 \\
42 & 75.46 & 74.44 & 4.51 & 0.2615 \\
43 & 73.75 & 73.40 & 4.66 & 0.7106 \\
44 & 71.25 & 69.50 & 5.39 & 0.9002 \\
Mean & 76.77 & 76.07 & 3.77 & 0.3600 \\
\hline
\end{tabular}


Table 2 shows the results of water intake percentage relative to bird body weight. Breeders drinking from nipple drinkers presented significantly lower water intake relative to body weight compared with the bell drinkers during the evaluated weeks. These results are consistent with the findings of Macari (1996) and Roush \& Borgan (1987), who also observed lower water consumption with the use of nipple drinkers. However, those authors refer to this lower intake as partial water deprivation as there was also lower egg production, which was not the case in the present study, where egg production was not influenced by the type of drinker.

Table $\mathbf{2}$ - Weekly water intake percentage relative to body weight as a function of drinker type.

\begin{tabular}{|c|c|c|c|c|c|c|}
\hline \multirow{2}{*}{$\begin{array}{c}\text { Week } \\
37\end{array}$} & \multicolumn{2}{|c|}{ Bell drinker } & \multicolumn{2}{|c|}{ Nipple drinker } & \multirow{2}{*}{$\begin{array}{r}\text { CV (\%) } \\
15.10 \\
\end{array}$} & \multirow{2}{*}{$\begin{array}{l}\text { P Value } \\
0.0153\end{array}$} \\
\hline & 10.75 & a & 9.41 & $b$ & & \\
\hline 38 & 10.94 & $a$ & 8.21 & $b$ & 17.92 & 0.0030 \\
\hline 39 & 11.31 & a & 8.68 & $b$ & 12.59 & $<0.0001$ \\
\hline 40 & 11.22 & $a$ & 9.53 & $\mathrm{~b}$ & 13.32 & 0.0033 \\
\hline 41 & 10.96 & $a$ & 8.95 & $b$ & 16.61 & 0.0034 \\
\hline 42 & 11.52 & $a$ & 8.56 & $b$ & 11.15 & $<0.0001$ \\
\hline 43 & 9.83 & $a$ & 8.47 & $\mathrm{~b}$ & 15.11 & 0.0153 \\
\hline 44 & 10.30 & $a$ & 8.14 & $b$ & 9.14 & $<0.0001$ \\
\hline Mean & 10.85 & & 8.74 & & 14.34 & 0.1566 \\
\hline
\end{tabular}

$a>b(p<0.05)-S N K$ test

May et al. (1997), in a study on the influence of drinker type on relative water intake of broilers, showed that nipple drinkers resulted in water deprivation, and that it can be made worse by incorrect nipple drinker management. Nipple drinkers are not easy to regulate. Quichimbo et al. (2013) demonstrated that broiler performance was negatively affected when nipple drinkers were placed too high, noting that height is a critical factor when using these type of drinker. Cornelison et al. (2005) compared the use of eight different commercial brands of nipple drinker for six weeks, and described differences in flow rates among the brands, highlighting the importance of the precise management of this equipment.

Table 3 presents mortality results obtained during the experimental period, which were not statistically different between treatments. Macari (1996) found higher mortality in broilers during the summer in southeast Brazil in farms equipped with bell drinkers compared with those with nipple drinkers. According to Amaral et al. (2001), the better performance of nipple drinkers may be related to lower exposure of the water to the environment, which consequently presents better quality.
Table 3 - Weekly mortality (\%) of broiler breeders as a function of drinker type.

\begin{tabular}{ccccc}
\hline Week & Bell drinker & $\begin{array}{c}\text { Nipple } \\
\text { drinker }\end{array}$ & CV (\%) & P Value \\
\hline 37 & 0.118 & 0.109 & 39.27 & 0.7798 \\
\hline 38 & 0.181 & 0.150 & 40.23 & 0.5381 \\
\hline 39 & 0.120 & 0.075 & 58.57 & 0.3078 \\
\hline 40 & 0.126 & 0.061 & 41.59 & 0.0575 \\
\hline 41 & 0.185 & 0.144 & 25.39 & 0.2150 \\
\hline 42 & 0.160 & 0.075 & 47.18 & 0.0754 \\
\hline 43 & 0.160 & 0.100 & 43.42 & 0.2169 \\
\hline 44 & 0.190 & 0.120 & 28.82 & 0.0803 \\
\hline Mean & 0.155 & 0.104 & 40.03 & 0.2787 \\
\hline
\end{tabular}

Poultry litter relative humidity (Table 4) was significant lower between weeks 38 and 41 in the pens equipped with nipple drinkers, resulting in better litter quality. According to Macari (1996), optimal poultry litter relative humidity for growing broilers is within the range of 20 to $40 \%$. Cornelison et al. (2005), comparing eight different commercial brands of nipple drinkers, reported 29.64 to $43.94 \%$ relative humidity in the litter of 42 -d-old male broilers. Poultry litter relative humidity values obtained in the present study with nipple drinkers are consistent with those findings, but higher humidity was observed when bell drinkers were used.

Table 4 - Weekly poultry litter relative humidity (\%) of as a function of drinker type.

\begin{tabular}{ccccc}
\hline Week & Bell drinker & $\begin{array}{c}\text { Nipple } \\
\text { drinker }\end{array}$ & CV (\%) & P Value \\
\hline 37 & 39.97 & 40.91 & 14.49 & 0.8285 \\
\hline 38 & $45.55 \mathrm{a}$ & $32.89 \mathrm{~b}$ & 11.23 & 0.0066 \\
\hline 39 & $48.14 \mathrm{a}$ & $31.31 \mathrm{~b}$ & 11.61 & 0.0021 \\
\hline 40 & $45.69 \mathrm{a}$ & $34.30 \mathrm{~b}$ & 9.29 & 0.0049 \\
\hline 41 & 43.33 & 39.47 & 14.35 & 0.5626 \\
\hline 42 & 42.48 & 35.43 & 7.27 & 0.1306 \\
\hline 43 & 47.46 & 45.95 & 3.59 & 0.3594 \\
\hline 44 & 39.57 & 39.27 & 4.60 & 0.8858 \\
\hline Mean & 44.02 & 37.44 & 9.55 & 0.3500 \\
\hline
\end{tabular}

$a>b(p<0.05)-$ SNK test

Egg weight (Table 5) was significantly affected by drinker type in weeks 39 and 40, which broiler breeders drinking from bell drinkers produced heavier eggs than those in pens equipped with nipple drinkers. Egg weight is directly related to hatchling weight, which affects overall broiler performance (Muerer et al., 2008). Togashi et al. (2008), in studies with commercial layers, did not observe any egg weight differences when comparing cup drinkers with nipple drinkers for nine weeks. Ramos et al. (1990) reported that the layers produced heavier eggs when drinking from bell drinkers relative to nipple drinkers. 
Table 5 - Weekly egg weight of broiler breeders as a function of drinker type.

\begin{tabular}{|c|c|c|c|c|}
\hline Week & Bell drinker & $\begin{array}{l}\text { Nipple } \\
\text { drinker }\end{array}$ & CV (\%) & P Value \\
\hline 37 & 63.66 & 63.33 & 7.17 & 0.4233 \\
\hline 38 & 65.00 & 64.75 & 7.93 & 0.4734 \\
\hline 39 & $64.95 \quad a$ & 63.79 & 6.99 & 0.0002 \\
\hline 40 & $65.53 \quad a$ & 64.94 & 6.44 & 0.0421 \\
\hline 41 & 65.40 & 65.34 & 6.52 & 0.8523 \\
\hline 42 & 68.13 & 68.24 & 5.24 & 0.6431 \\
\hline 43 & 66.98 & 67.33 & 5.46 & 0.1671 \\
\hline 44 & 65.98 & 65.84 & 6.28 & 0.7243 \\
\hline Mean & 65.70 & 65.45 & 6.50 & 0.4157 \\
\hline
\end{tabular}

$a>b(p<0.05)-$ SNK test

Eggshell percentage (Table 6) was significantly influenced by drinker type, with higher percentages obtained in weeks 37, 38, and 48 with bell drinkers compared with nipple drinkers. Eggshell percentage is a direct indication of eggshell quality. Narushin \& Romanov (2002) described the relationship between eggshell thickness and hatchability relative to broiler breeder age and observed that older breeders produced thinner eggs with thinner shells and lower hatchability. In the present study, eggshell percentage reduced as broiler breeders aged, which is consistent with the findings of Rosa (2002) that eggs from older breeders are frequently larger, and consequently present lower eggshell percentage.

Table $\mathbf{6}$ - Weekly eggshell percentage of broiler breeders as a function of drinker type.

\begin{tabular}{ccccc}
\hline Week & Bell drinker & Nipple drinker & CV (\%) & P Value \\
\hline 37 & $13.37 \mathrm{a}$ & $12.68 \mathrm{~b}$ & 14.47 & $<0.0001$ \\
\hline 38 & $12.66 \mathrm{a}$ & $12.02 \mathrm{~b}$ & 19.10 & $<0.0001$ \\
\hline 39 & 12.20 & 12.12 & 12.79 & 0.4538 \\
\hline 40 & $12.55 \mathrm{a}$ & $12.33 \mathrm{~b}$ & 11.14 & 0.0226 \\
\hline 41 & 11.63 & 11.58 & 9.97 & 0.5775 \\
\hline 42 & 11.61 & 11.48 & 8.93 & 0.0814 \\
\hline 43 & 11.28 & 11.38 & 9.32 & 0.1578 \\
\hline 44 & 12.11 & 11.98 & 6.70 & 0.0791 \\
\hline Mean & 12.18 & 11.95 & 11.55 & 0.2287 \\
\hline
\end{tabular}

$a>b(p<0.05)-$ SNK test

Egg specific gravity (Table 7) was significantly different between treatments in weeks 37 and 38, with higher values obtained in egg from broiler breeders drinking from bell drinkers. On the other hand, Togashi et al. (2008) did not find any influence of nipple or cup drinker on the specific gravity of commercial layer eggs. In the present study, egg specific gravity decreased as birds aged. According to Keshavarz \& Nakajima (1993), this is related to the reduction in calcium retention rates as a function of age, as they observed $60 \%$ calcium retention rate in young layers and $40 \%$ in older layers. This may be attributed to the fact that older hens have reduced calcium intestinal absorption and bone mobilization capacity. As hens age, egg weight increases in up to $20 \%$, but eggshell weight does not proportionally increases.

Table 7 - Weekly specific gravity $(\mathrm{g} / \mathrm{mL})$ of the eggs laid by broiler breeders as a function of drinker type

\begin{tabular}{|c|c|c|c|c|c|c|}
\hline Week & Bell drinke & & Nipple dri & & CV (\%) & P Value \\
\hline 37 & 1079 & a & 1077 & $b$ & 0.118 & $<0.0001$ \\
\hline 38 & 1077 & $a$ & 1076 & $b$ & 0.152 & 0.0139 \\
\hline 39 & 1074 & & 1074 & & 0.178 & 0.8793 \\
\hline 40 & 1075 & & 1075 & & 0.147 & 0.8611 \\
\hline 41 & 1074 & & 1075 & & 0.132 & 0.9492 \\
\hline 42 & 1072 & & 1073 & & 0.062 & 0.7361 \\
\hline 43 & 1071 & & 1071 & & 0.041 & 0.1225 \\
\hline 44 & 1072 & & 1072 & & 0.068 & 0.1314 \\
\hline Mean & 1075 & & 1074 & & 0.112 & 0.5276 \\
\hline
\end{tabular}

$a>b(p<0.05)-$ SNK test

In the present study, the water collected from bells drinkers and nipple drinkers did not present any total coliform, fecal coliform, or Escherichia coli contamination during the experimental weeks. These results may be explained by the daily cleaning management of the drinkers and by the permanent chlorination (3-5 ppm Cl) of the drinking water used during the experiment.

\section{CONCLUSIONS}

The results of the present study showed that the use of nipple drinkers promoted lower water intake and better poultry litter quality, but did not affect egg production or mortality. Therefore, nipple drinkers may be used for broiler breeders during lay.

\section{REFERENCES}

Amaral LA, Togashi CK, Angela HL, Freitas ER, Guastalli EAL, Buim MR, Gama NMSQ. Qualidade higiênico-sanitária e demanda de cloro da água de dessedentação de galinhas de postura coletadas em bebedouros tipo nipple e taça. Revista Brasileira Ciência Avícola 2001;3(3):249-255.

Aviagen Brasil. Manual de manejo de matrizes Ross 308. $2^{\mathrm{a} e d}$. Campinas; 2008. 79p.

Bruno LDG, Maiorka A, Macari M, Furlan RL, Givisiez PEN. Water intake behavior of broiler chickens exposed to heat stress and drinking from 
bell or and nipple drinkers 2011 Brazilian Journal of Poultry Science 2011;13(2):147-152

Carneiro APM, Pascoal LAF, Watanabe PH, Santos IB, Lopes JM, Arruda AJCB. Farelo de Babaçu em rações para frangos de corte na fase final: Desempenho, rendimento de carcaça e avaliação econômica. Ciência Animal Brasileira 2009;10(1):40-47.

Cornelison JM, Hancock AG, Willians AG, Davis, LB, Allen NL, Watkins SE. Evaluation of nipple drinkers and the lott system for determining appropriate water flow for broilers. Avian Advice 2005;7(3):1-4.

Gama NMSQ, Ângela HL, Freitas ER, Guastalli EL, Togashi CK, Buim MR. Desempenho de poedeiras comerciais consumindo água filtrada. Arquivos Instituto Biológico 2009; 76(3):347-352.

Jafari RA, Fazlara A, Goyahi M. An Investigation into salmonella and fecal coliform contamination of drinking water in broiler farms in Iran. International Journal of Poultry Science 2006;5:491-493.

Karimi V, Zahraei Salehi T, Sadegh M, Jaafarnejad, S. The relation of water contamination and Colibacillosis occurrence in poultry farms in Qom province of Iran. Iranian Journal of Veterinary Research 2011;12( 2):133-138

Keshavarz K, Nakajima S. Re-evaluation of calcium and phosphorus requirements of laying hens for optimum performance and eggshell quality. Poultry Science 1993;72: 144-153.

Klosowisk ES, Nunes RV, Navarini FC, Pozza PC, Nunes CV, Orlando C, Eyng $C$, Richard. Bebedouros para poedeiras semi pesadas no verão. Revista brasileira de saúde e produção animal 2009;10:379-389

Manning L, Chadd SA, Baines RN. Water consumption in broiler chicken: A welfare indicator. World's Poultry Science Journal 2007;63:63-71.

Macari, M. Água na avicultura industrial. Jaboticabal: FUNEP, 1996. 128p.

May JD, Lott BD, Simmons JD. Water consumption by broilers in high cyclic temperatures: Bell versus nipple waterers. Poultry Science 1997;76:944-947.
Muerer RFP, Valle FLP, Santos AS, Zanatta CP, Dahlke F, Maiorka A, Oliveira E. Interação entre idade da matriz e peso do ovo no desempenho de frangos de corte. Archives of Veterinary Science 2008;13(3):197-203.

Narushin VG, Romanov MN. Egg physical characteristics and hatchability. World's Poultry Science Journal 2002;58 (3):297-303.

Quichimbo C, Quintana J, Rodríguez-Saldaña D, López-Coello C, Gómez S, Castellanos F. Effect of Nipple Type Drinker Height on Productive Parameters of Broilers. International Journal of Poultry Science 2013; 12(3):144-147.

Ramos NC, Gernat AG, Adams, W. Effects of cage, shape, age at housing and types of rearing and layer waterers on the productivity of layers. Poultry Science 1990;69:217-223.

Rosa OS, Guidoni, AL, Lima IL, Bersch FXR. Influência da temperatura de incubação em ovos de matrizes de corte com diferentes idades e classificados por peso sobre os resultados de incubação, Revista Brasileira de Zootecnia 2002;31(2):1011-1016.

Roush WB, Boggan GD. Effect of watering devices on performance during pullet-rearing and cage-laying phases of Single Comb White Leghorn laying hens. Poultry Science 1987;66:1431-1436.

Statistical Analysis System. System for Microsoft Windows. Cary; 2001

Soares NS, Togashi CK, Amoroso L. Ingestão de água pelas aves através do uso de diferentes tipos de bebedouros. In: Macari M, Soares NM, editors. Água na Avicultura Industrial. Campinas: FACTA; 2012. p.309321

Togashi CK, Angela HL, Freitas ER, Guastalli AL, Buim MR, Soares NM, Gama NS. Efeitos do tipo de bebedouro sobre a qualidade da água e o desempenho e qualidade dos ovos de poedeiras comerciais. Revista Brasileira de Zootecnia 2008;37(8):1450-1455.

Watkins S. The campaign for quality drinking water continues. Avian Diseases 2002;3(3):7-9. 